mainly the narrative of the expedition by Sir Douglas Mawson, and most of it has been long anticipated by the same author's popular volume entitled "The Home of the Blizzard" and Captain J. K. Davis's "With the Aurora in the Antarctic". Nevertheless, the official record of voyages, sledge journeys and discoveries should be valuable to future explorers. Most important, however, are the maps of various parts of the coast-line of Antarctica showing in full the details of the expedition's work. They include a large-scale plan of the surroundings of the expedition's main base at Cape Denison in King George Land, and maps of Queen Mary Land, King George Land, and the Charnockite coast east of Commonwealth Bay, and also track charts of the several voyages of the Aurora. Another useful feature is the inclusion of gazetteers of all names, giving not only the character of the feature, but also the origin of the name. The latter will be most useful for the future historian of the Antarctic. Only too often the origin of names given to features in polar regions is lost for want of such records by the explorers themselves.

\section{Scientific and Industrial Photographers}

THE Birmingham General Branch of the Association of Scientific Workers arranged for a lecture by Mr. Herbert E. Zerkowsky, of the British Cast Iron Research Association, on April 13, at the Chamber of Commerce, Birmingham, in connexion with the exhibition "Photography in Science and Industry". Mr. Zerkowsky started by giving a review of the development of photographic technique and paid tribute to the research work done by the manufacturers of photographic materials in Great Britain and to the contributions made by those who employ photography daily as a tool, and also by the amateurs. Special reference was made to the question of the salaries of photographers in the Civil Service and in industry, which are generally far below the average pay of those employed in the darkroom and in portrait photography. Mr. Zerkowsky pointed out that those who use photography for technical and scientific purposes are required to have first-class technical and scientific knowledge besides their photographic skill and experience. These workers, which he suggested should be called 'research photographers', have no organization to look after their interests and to ensure facilities for further studies and training young people, apart from the Association of Scientific Workers. He suggested the formation of a Group of Scientific and Industrial Photographers within the Association.

\section{Potato Virus Diseases in Victoria}

PAMPhLeT No. 110 of the Commonwealth of Australia Council for Scientific and Industrial Research (314 Albert Street, East Melbourne, Victoria, 1941), by J. G. Bald and A. T. Pugsley, considers the effects of the potato virus diseases named $X, A, Y$, and leaf-roll, upon the most important varieties of that crop grown in Victoria. The variety Carman is almost entirely infected with virus $X$, is very susceptible to $A$ and $Y$, and less so to leaf-roll. Up-to-date, like its namesake in Great Britain, is susceptible to most of the serious viruses, but in Victoria it possesses practical field immunity from virus $A$. The Snowflake variety is not very subject to aphis-borne virus diseases, though the stock is almost entirely affected with virus $X$. A survey of suitable districts for the propagation of disease-free potato stocks is being made, and further studies of the effects of multiple infection by the viruses mentioned above, and those denoted by $F$ and $G$, are in progress.

\section{Palæontographical Society}

Tributes were paid to Sir Arthur Smith Woodward on his retirement from the presidential chair at the annual general meeting of the Palæontographical Society held in the Geological Society's rooms at Burlington House on April 21. Sir Arthur had been president for nine years, following thirty years as secretary of this Society. During his period of secretaryship, in addition to the ordinary duties of that office, he contributed two important monographs on Cretaceous fishes to the Society's series of volumes which describe and illustrate British fossils. In recognition of Sir Arthur's outstanding services to the Society, he has been elected an honorary member. $\mathrm{He}$ is succeeded as president by Prof. H. L. Hawkins, professor of geology in the University of Reading.

\section{Sir Sidney Burrard}

Prof. J. L. Simonsen writes: "In his brief obituary notice in NaTuRE of April 10, p. 414, of the late Sir Sidney Burrard, Sir Gerald Lenox-Conyngham omitted to mention one very important contribution to the advancement of science in India which we owe to Sir Sidney. When the formation of the Indian Science Congress, now the Indian Science Congress Association, was under consideration in the years 1911-12, it is very doubtful if any progress would have been made had it not been for the enthusiastic support which the proposal received from Sir Sidney Burrard and Sir Henry Hayden. It was due mainly to their representations that this body was from the outset recognized by the Government of India and by the local governments. Sir Sidney was president of the Congress at Lucknow in 1916 and during the remaining period of his service in India he always followed its meetings with the greatest interest".

\section{The Night Sky in May}

New moon occurs on May 4d. 09h. 43m. U.T., and full moon on May 19d. 21h. $13 \mathrm{~m}$. The following conjunctions with the moon will take place: May 5d. 22h., Mercury $8^{\circ}$ N. ; May 6d, 15h., Saturn $3^{\circ}$ N.; May 7d. 18h., Venus $6^{\circ}$ N.; May 9d. 21h., Jupiter $3^{\circ}$ N. ; May 28d. 10h., Mars $2^{\circ} \mathrm{N}$. Occultations of stars brighter than magnitude 6 are as follows: May 6d. 9h. 01.0m., $\alpha$ Tau. $(D)$; May 6d. 10h. $07 \cdot 0 \mathrm{~m} .$, \& Tau. $(R)$; May 12d.21h. $27 \cdot 6 \mathrm{~m}$., v Leo $(D)$. The times are given for Greenwich and $D$ and $R$ refer to disappearance and reappearance respectively. Mercury is stationary on May 12 and in inferior conjunction on May 23. Venus sets at $23 \mathrm{~h}$. $30 \mathrm{~m}$. about the middle of the month and is a conspicuous object in the western sky. Mars souths at $8 \mathrm{~h}$. in the middle of the month, rising at $2 \mathrm{~h} .30 \mathrm{~m}$. The planet is in Aquarius and is rather low for good observation. Jupiter, in Gemini, sets about midnight in the middle of the month. Saturn cannot be seen as it is too close to the sun. The times refer approximately to the latitude of Greenwich. The Aquarid shower of meteors is active in the first week in May, but it is generally very feeble and supplies few meteors. 